\title{
Interaction between Bean yellow mosaic virus and Botrytis fabae on Faba Bean and the Possibility of their Control by Plant Growth Promoting rhizobacteria
}

\author{
A.A. Hilal ${ }^{*}$; Radwa M. Shafie ${ }^{* *}$ and H.H.A. \\ El-Sharkawy \\ * Medicinal \& Aromatic Plant Dis. Res. Dept., Plant Pathol. Res. Inst., ARC, Egypt. \\ ** Virus \& Phytoplasma Res. Dept., Plant Pathol. Res. Inst., ARC, Egypt. \\ *** Mycology Res. \& Plant Dis. Survey Dept., Plant Pathol. Res. Inst., ARC, Egypt.
}

\begin{abstract}
Taba bean plants infected by Bean yellow mosaic virus (BYMV) 1 were more susceptible to infection by Botrytis fabae using the detached leaf method. Lesion grades, rate and extent of lesion spread as well as sporulation of $B$. fabae were increased on leaves infected with virus compared with healthy ones. Lesions caused by $B$. fabae on leaves infected by BYMV, were larger and developed more rapidly than on virus- free plants. Sporulation on lesions caused by BYMV began earlier and was more abundant than on virus-free plants. The indirect ELISA was carried-out to confirm the identity of the virus. Five strains of plant growth promoting rhizobacteria (PGPR), i.e. Rhizobacterin, Cerealin, Microbien, Nitrobien and Biogen were tested as foliar spraying or seed soaking for induction of systemic resistance (ISR) in faba bean plants to BYMV and B. fabae. Foliar treatment with Microbien showed higher reduction in the level of disease severity and disease incidence for either BYMV and B. fabae. Spraying faba bean with Microbien significantly increased abscisic acid (ABA), salicylic acid (SA) and jasmonic acid (JA) levels than the other treatments. The treatments tested increased phenolic compounds and the activities of peroxidase and polyphenoloxidase in the tested plants compared to healthy materials.
\end{abstract}

Keywords: B. fabae, Bean yellow mosaic virus (BYMV), Chocolate spot, Faba bean, Induction of systemic resistance (ISR), Interaction, Peroxidase, Phenols, Plant growth promoting rhizobacteria (PGPR), Polyphenoloxidase

Faba bean, Vicia faba L., is considered as one of the most important food legumes in Egypt. The plants attack by several pathogens including viral and fungal diseases causing a considerable yield losses (El-Tahlawy et al., 2005 and ElBramawy \& Shaban, 2010).Viral diseases have an important role because they not only cause direct damage to the host, but also predisposing the plant to secondary invaders (Mahgoub et al., 1997). Among faba bean viruses, Bean yellow mosaic virus (BYMV) is considered one of the most serious viruses affecting faba bean plants in Egypt (Radwan et al., 2008). Also, chocolate spot caused by Botrytis fabae is considered the most destructive fungal disease causing serious damage to the plant growth and seed yield (Mahmoud et al., 2011). Interaction between viral and fungal 
diseases might show a synergistic reaction (Ajyi and Dewar, 1983), or antagonistic reaction (Ataga et al., 1999) or no obvious effects (Jenns and Kuc, 1977).

Infection by various viral diseases increased susceptibility to several fungal infections in different plant hosts, such as oats (Comeau and Pelletier, 1976), pepper (Pieczarka and Zitter, 1981), Faba bean (Omar et al., 1986), asparagus (Evans and Stephens, 1989). There are relatively few studies on the influence of the fungusinfected plants on subsequent virus inoculation. Number of lesions formed on a Tobacco necrosis virus- infected cucumber cotyledons was not affected by prior infection of the opposite cotyledon by Colletotrichum lagenarium (Jenns and Kuc, 1977). Management of both plant viral and fungal diseases can be accomplished throught inducing plant defense mechanisms by using nonpathogenic rhizobacteria (Van Loon et al., 1998), which have the ability to induce a state of systematic resistance in plants that provides protection against a broad spectrum of microorganisms. This approach has been referred to as induced systemic resistance (Park et al., 2007). BYMV challenged plants emerged from two plant growth promoting rhizobacteria, i.e. Pseudomonas fluorecens and Rhizobium leguminosarum inoculated seeds showed a pronounced and significant reduction in disease incidence percentages in the challenged plants (Elbadry et al., 2006). Faba bean plants grown from $R$. leguminosarum treated seeds and sap- inoculated with BYMV yielded a significant reduction in disease incidence (Al-Ani and Adhab, 2013). The dual inoculation of faba bean seeds with $R$. leguminosarum and Trichoderma sp. reduced chocolate spot disease caused by B. fabae (Saber et al., 2009). Foliar application of $P$. fluorescens on grapevine gave a good results in inducing systemic resistance against $B$. cinerea (Verhagen et al., 2010).Treating seeds and soil with $P$. fluorescens suspension induced reduction in CMV accumulation in melon plants (Al-Ani and Adhab, 2012).

The aim of this study was to determine the potential of five Plant growth promoting rhizobacteria (PGPR) strains on induction of systemic resistance in faba bean plants to BYMV and B. fabae infection.

\section{Materials and Methods}

Plant materials and growing conditions:

Seeds of faba bean (Vicia faba L.) cv. Giza 716 were obtained from Legume Crops Dept., Inst. of Crop Production, Agric. Res. Centre. Seeds were sown in pots (25 cm diam.). Seeds of Chenopodium amaranticolor were sown in pots $(20 \mathrm{~cm}$ diam.). The pots were watered and maintained in a greenhouse $\left(22-25^{\circ} \mathrm{C}\right)$. C. amaranticolor seedlings were transplanted to other pots (10-cm-diam.) containing mixture of sand and clay soil $(1: 3 \mathrm{w} / \mathrm{w})$ at the rate of two seedlings/pot.

\section{BYMV inoculation:}

Bean yellow mosaic isolate and antiserum specific to BYMV were obtained from Virus and Phytoplasma Res. Dept., Plant Pathol. Res. Inst. Agric. Res. Centre. The identity of the virus was confirmed by indirect ELISA technique (Converse and Martin, 1990). Virus inoculum was prepared by inoculating mechanically faba bean seedlings (at three leaves stage) with the virus isolate according to Noordam (1973). 


\section{Preparation of Botrytis fabae inoculum:}

A virulent, identified B. fabae isolate was kindly obtained from Legume and Forage Crop Dis. Res. Dept. and grown on faba bean leaf extract agar medium for 7 days at $18^{\circ} \mathrm{C}$ (Leach and Moore,1966), spores were separated using a camel hair brush, counted using a haemocytometer slide, then adjusted to $2.5 \times 10^{5}$ spore $/ \mathrm{ml}$ and used immediately.

\section{Rhizobacteria:}

Biogen (Azotobacter sp.), Cerealin (Azotobacter sp., Asosprillum sp. \& Bacillus polymixa), Microbien (Azotobacter sp., Asosprillum sp., B. megaterium, Pseudomonas fluorescens \& Rhizobium leguminosorum), Nitrobien (Azotobacter sp. \& Asosprillium sp.), Rhizobacterin (Azotobacter sp., Asosprillum sp. \& R. leguminosarum) were kindly provided by Biofertilizer Production Unit, Soil, Water and Environ. Res. Inst., Agric. Res. Centre. The concentration of the bacteria in the suspension was $10^{8} \mathrm{cfu} / \mathrm{ml}^{-1}$.

Effect of pre- inoculation with BYMV on subsequent infection by chocolate spot fungus:

Detached leaf experiment:

Faba bean plants with three fully expanded leaves were mechanically inoculated with BYMV or buffer solution as control. After three weeks, thirty five leaves showing mosaic symptoms were detached from five plants of each treatment and labelled according to their positions from the base of the plant. The same number of leaves sprayed with buffer solution served as control. All leaves were placed in Petri dishes $(12 \mathrm{~cm}$. diam.) lined with wet filter paper. Four droplets $(10-\mu \mathrm{l})$ of B. fabae spore suspension $\left(2.5 \times 10^{5}\right.$ spores $\left./ \mathrm{ml}\right)$ were pipetted onto the upper leaf surface. Two leaflets were accommodated in each plate and incubated at $18^{\circ} \mathrm{C}$ under cool white fluorescent tubes. One and three days after inoculation, infection sites were assigned to one of several grades using the system devised by Mansfield \& Deverall (1974) based on the percentage of necrosis on the leaf surface beneath the inoculum droplet. Spreading of the lesions was measured after 7 days from inoculation. Lesion diameters were recorded daily for 3 to 7 days after fungal inoculation and the rate of lesion spread was calculated as the increase in lesion diameter $(\mathrm{mm})$ per day. Sporulation density after 10 days was recorded as $(-)$ nil, $(+)$ few, $(++)$ moderate, $(+++)$ dense. A scale of 1-5 categories was used to asses virus severity qualitatively according to virus symptoms, as follows: $1=$ no symptoms; $2=$ mild chlorotic patterns and slight distortion of leaves; 3-mosaic patterns on all leaves, leaf distortion; 4-mosaic patterns on all leaves, leaf distortion, and general reduction in leaf size; 5severe mosaic on all leaves and stunting of whole plant (Wydra and Verdier, 2002).

\section{Whole plant experiment:}

Ten faba bean seedlings ( 20 days old) for each treatment were inoculated with BYMV or buffer solution as control, after 20 days all plants were sprayed with $B$. fabae spore suspension at the rate of $2 \mathrm{ml} /$ plant $\left(2.5 \times 10^{5} \mathrm{spore} / \mathrm{ml}\right)$ with an atomizer to obtain fine mist on the inoculated plants. Plants were left under polyethylene bags for $24 \mathrm{hrs}$ to ensure high humidity then the bags were removed and the plants were kept under greenhouse conditions. Three and 9 days after Botrytis inoculation, lesion development was recorded as the percentage of leaf area 
infected on the basis of percentage of the total leaf area occupied by fungal lesions as described by Bernier et al. (1984). A scale of 1-5 categories was used to assess virus severity as mentioned before.

Effect of pre-inoculation with B. fabae on BYMV infectivity:

Twenty faba bean seedlings ( 20 days old) for each treatment were sprayed with $B$. fabae spore suspension $\left(2.5 \times 10^{5}\right.$ spore $\left./ \mathrm{ml}\right)$, while the control plants were sprayed with only sterilized water. After $24 \mathrm{hrs,}$, all the plants were inoculated with BYMV as mentioned before. Three weeks later, BYMV concentration in leaves No. 2 and 6 in both treatments was assayed using $C$. amaranticolor as a local lesion host.

Evaluation of plant growth promoting rhizobacteria (PGPR) efficiency on both $B Y M V$ and B. fabae infection:

Foliar treatment:

This experiment was conducted using Randomized Complete Block Design with five treatments and two controls (inoculated plants either with fungus or virus) each consisted of four replicate pots and five plants per pot. The five PGPR were applied as foliar sprays on the potted plants. Faba bean plants were pre-treated with PGPR by spraying the whole leaves twice, 20 and 40 days after sowing. Forty faba bean plants sprayed with distilled water only were served as control. Two days later, the treated plants with each inducer were inoculated with BYMV. Twenty faba bean plants in the control treatment were inoculated only with the virus (virus control). Forty two days after sowing, twenty faba bean plants were sprayed with the spore suspension of $B$. fabae $\left(2.5 \times 10^{5}\right.$ spore $\left./ \mathrm{ml}\right)$ (Fungus control), and the treated plants in each inducer treatment were sprayed with spore suspension of $B$. fabae. All plants were covered with polyethylene bags for 24 hrs to maintain high relative humidity, then kept under greenhouse conditions at $\left(18-20^{\circ} \mathrm{C}\right)$. After 45 days from sowing, the number of plants exhibiting BYMV symptoms was recorded. Percentage of disease incidence(PDI) was estimated according to the equation: PDI= Number of symptomatic plants/Total number of plants $\times 100$ (Reddy et al., 1983), while the disease severity (DS) percentage was calculated according to Wydra and Verdier (2002) as follows: $\mathrm{DS}(\%)=\sum \mathrm{n} \times \mathrm{v} / 5 \mathrm{~N} \times 100$ where, $\mathrm{n}$ : number of infected leaves in each category, $\mathrm{N}$ : total number of the leaves inspected, V: numerical value of the categories(1-5) and 5: maximum numerical values of symptom category. Chocolate spot symptoms, which appeared 7 days after inoculation, were scored as infection type and disease severity was assessed according to the 1-9 scale of Bernier et al. (1984) as follows:

Disease severity $\%=(\mathrm{n} \times \mathrm{v}) / 9 \mathrm{~N} \times 100$

Whereas:

$(n)=$ Number of plants in each category.

$(v)=$ Numerical values of symptoms category.

$(\mathrm{N})=$ Total numbers of plants.

(9)= Maximum numerical values of symptom category are as follows:

1 = No disease symptoms, or very small, specks; $3=$ Few small discrete lesions; $5=$ some coalesced lesions with some defoliation; 7 = Large coalesced sporulating lesions, $50 \%$ defoliation, some dead plants; $9=$ Extensive lesions on leaves, stems, and pods, sporulation, stem girdling, blackening and death of more than $80 \%$ of 
plants. In all cases, the indirect ELISA was carried-out to confirm the obtained results in this study.

Chocolate spot disease incidence (DI) caused by B. fabae was determined after 15 days from inoculation according to the following formula: DI= Number of infected leaflets/ Total number of tested leaflets $\times 100$ (Alemu and Alemu, 2013). While, efficacy $\%(\mathrm{E} \%)$ of each treatment in reducing disease severity percentage was assessed according to Rewal and Jhooty (1985) as follow:-E\% $=\% \mathrm{DS}$ in control - $\%$ DS in a treatment $/ \% \mathrm{DS}$ in the control.

\section{Seed treatment:}

Faba bean seeds bacterization was carried out according to the method of Dileep Kumar and Dube (1992) with some modification as follows: seeds were surface sterilized with $2.5 \%$ sodium hypochlorite for $5 \mathrm{~min}$. followed by rinsing in (1:29) mixture of hydrogen peroxide: distilled water for $30 \mathrm{~min}$. and dried under a sterile condition. These seeds were steeped in bacterial suspension $10^{8} \mathrm{cfu} / \mathrm{ml}^{-1}$ using the rate of $2 \mathrm{ml}$ per one gram seeds mixed with $10 \%$ Arabic gum for $1 \mathrm{hr}$ and then dried overnight at room temperature. Seeds steeped in only distilled water were served as control. Twenty days after sowing, the treated plants in each inducer treatment were inoculated with BYMV. Twenty faba bean plants in the control treatment were inoculated with the BYMV (virus control). After 20 days, twenty faba bean plants were sprayed with the spore suspension of $B$. fabae $\left(2.5 \times 10^{5}\right.$ spore/ml) (Fungus control), and the treated plants in each inducer treatment were sprayed with spore suspension of $B$. fabae at the rate of $2 \mathrm{ml} /$ plant. All plants were covered with polyethylene bags for 24 hrs to maintain high relative humidity, and then kept under greenhouse conditions.

Percentages of disease incidence (DI) and disease severity (DS) of BYMV were estimated as mentioned before. Whereas, disease severity and incidence of chocolate spot and efficacy percentage (E \%) of each treatment were also estimated. All results were confirmed using indirect ELISA as described by Koeing (1981).

Determination of some phytochemical components:

Determination of endogenous hormones (abscisic acid, salicylic acid and jasmonic acid) in leaves of the treated plants and in control plants inoculated with BYMV or B. fabae was carried out according to Lee et al. (1989). Ten grams fresh weight of the leaf samples were used for each replicate of each treatment for determination of phenolic compounds (mg/ $100 \mathrm{~g}$ of plant fresh wt.) according to Maliak and Singh (1980). While, Two grams fresh weight of the leaf samples were used for each replicate for determination the activity of some oxidative enzymes. Peroxidase activity was spectrophotometrically determined by measuring the oxidation of pyrogallol in the presence of $\mathrm{H}_{2} \mathrm{O}_{2}$ at $470 \mathrm{~nm}$ (Maxwell and Bateman, 1967). The activity of polyphenoloxidase enzyme was determined according to the method of Galeazzi et al. (1981).

Statistical analysis:

Data were analysed with the statistical analysis system SAS. All multiple comparisons were first subjected to analysis of variance (ANOVA) comparison among means was carried out according to Duncan's multiple range test (Duncan, 1995). 


\section{R e s u l t s}

Effect of pre-inoculation with BYMV on subsequent infection of chocolate spot disease:

A. Detached leaf experiment:

Data in Table (1) and (Fig.1) reveal that chocolate spot lesion developed more rapidly on BYMV- infected leaves $(5.8 \mathrm{~mm}$ in leaf number 1$)$ than corresponding BYMV free leaves(4.6). Infection grade differences were noticed one day after inoculation. Old leaves in virus-infected plants showed high susceptibility to the fungus compared with the corresponding leaf of virus- free leaves followed by the young leaves(with severe virus symptoms). The spread of lesions tends to decrease gradually according to the position of leaves. The same trend was observed in case of infection grades 1 day after inoculation, in which the values tend to decrease from 56.7 in leaf number 1 to reach 43.5 in leaf number 7 . Lesion also spread more rapidly after three days from inoculation (76.0 in leaf number 1) and the rate of spreading per day was greater in BYMV-infected leaves (1.7) (Fig.2). Sporulation was more extensive on virus- infected leaves than virus free ones. In both BYMVfree and BYMV- infected plants, susceptibility to $B$. fabae infection increased with increasing leaf age.

Table 1. Lesion development and sporulation of $B$. fabae on BYMV free and BYMV infected detached leaves

\begin{tabular}{|c|c|c|c|c|c|c|c|c|c|c|c|}
\hline \multirow{2}{*}{ 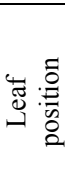 } & \multirow{2}{*}{ 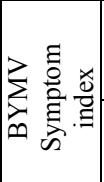 } & \multicolumn{2}{|c|}{$\begin{array}{c}\text { Infection grades } \\
1 \text { day after } \\
\text { inoculation }\end{array}$} & \multicolumn{2}{|c|}{$\begin{array}{c}\text { Infection grades } \\
3 \text { days after } \\
\text { inoculation } \\
\end{array}$} & \multicolumn{2}{|c|}{$\begin{array}{l}\text { Lesion spread } \\
(\mathrm{mm})\end{array}$} & \multicolumn{2}{|c|}{\begin{tabular}{|c|} 
Rate of lesion \\
Spread (mm) per \\
day
\end{tabular}} & \multicolumn{2}{|c|}{ Sporulation } \\
\hline & & $\begin{array}{l}\text { BYMV } \\
\text {-free }\end{array}$ & $\begin{array}{l}\text { BYMV } \\
\text {-infected }\end{array}$ & $\begin{array}{l}\text { BYMV } \\
\text {-free }\end{array}$ & $\begin{array}{l}\text { BYMV } \\
\text {-infected }\end{array}$ & $\begin{array}{l}\text { BYMV } \\
\text {-free }\end{array}$ & $\begin{array}{l}\text { BYMV } \\
\text {-infected }\end{array}$ & $\begin{array}{l}\text { BYMV } \\
\text {-free }\end{array}$ & $\begin{array}{l}\text { BYMV } \\
\text {-infected }\end{array}$ & $\begin{array}{l}\text { BYMV } \\
\text {-free }\end{array}$ & $\begin{array}{l}\text { BYMV } \\
\text {-infected }\end{array}$ \\
\hline 1 & 2 & 46.2 & 56.7 & 67.0 & 76.0 & 4.6 & 5.8 & 1.3 & 1.7 & ++ & +++ \\
\hline 2 & 2 & 43.2 & 45.0 & 59.5 & 74.5 & 4.4 & 5.0 & 1.2 & 1.4 & ++ & +++ \\
\hline 3 & 2 & 41.5 & 51.5 & 52.5 & 74.0 & 3.0 & 3.7 & 1.0 & 1.3 & ++ & +++ \\
\hline 4 & 3 & 36.0 & 38.0 & 50.7 & 59.0 & 2.2 & 3.9 & 1.1 & 1.2 & ++ & +++ \\
\hline 5 & 3 & 31.2 & 38.5 & 41.0 & 53.5 & 2.3 & 3.0 & 0.5 & 1.0 & + & ++ \\
\hline 6 & 4 & 30.7 & 37.0 & 34.5 & 59.0 & 2.2 & 3.5 & 0.9 & 1.2 & + & +++ \\
\hline 7 & 5 & 28.5 & 43.5 & 41.0 & 72.0 & 2.1 & 4.3 & 0.8 & 1.4 & + & +++ \\
\hline \multicolumn{2}{|c|}{ LSD at 0.05} & 2.6 & 1.8 & 5.5 & 1.7 & 5.4 & 1.7 & 0.3 & 0.2 & ------ & ------ \\
\hline
\end{tabular}

$\begin{array}{ll}-=\text { Nill }, \quad+=\text { few }, & ++=\text { Moderate }, \quad+++ \\ * 1 \text { : oldest leaf; } & * * 7 \text { : youngest leaf }\end{array}$

\section{B. Whole plant experiment}

Results in Table (2) indicate that, lesion developed more rapidly in BYMVinfected plants (70.5 after 9 days from inoculation in leaf number 1) than BYMV free plants (56.2). As noted with detached leaves, differences between control and virus - infected plants were most marked in old leaves. Chocolate spot symptoms appeared more quickly on detached leaves than on those still attached to plants of corresponding age. 


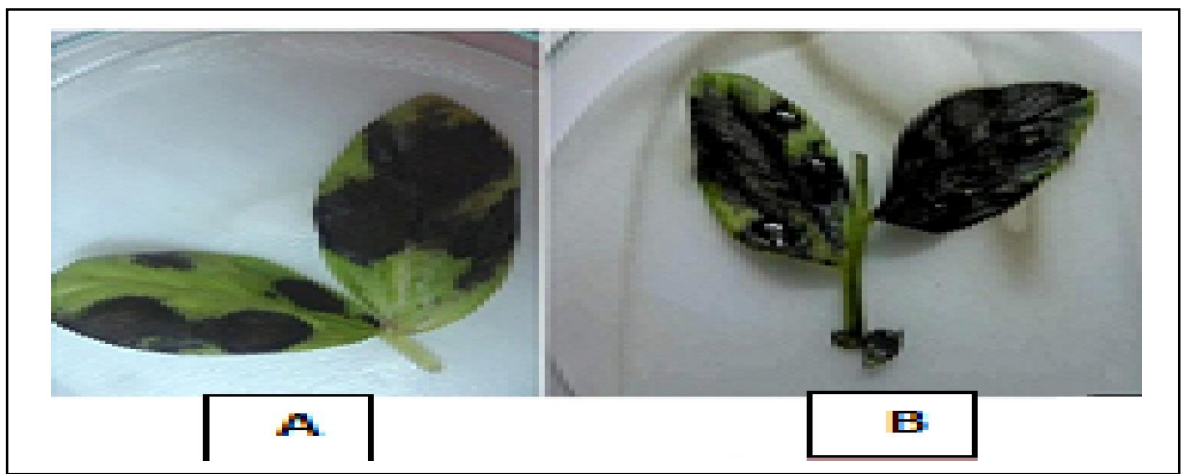

Fig. 1. Development of $B$. fabae on faba bean leaves with and without virus infection (A: BYMV- free leaves \& B: BYMV-infected) 5-days after fungal inoculation.

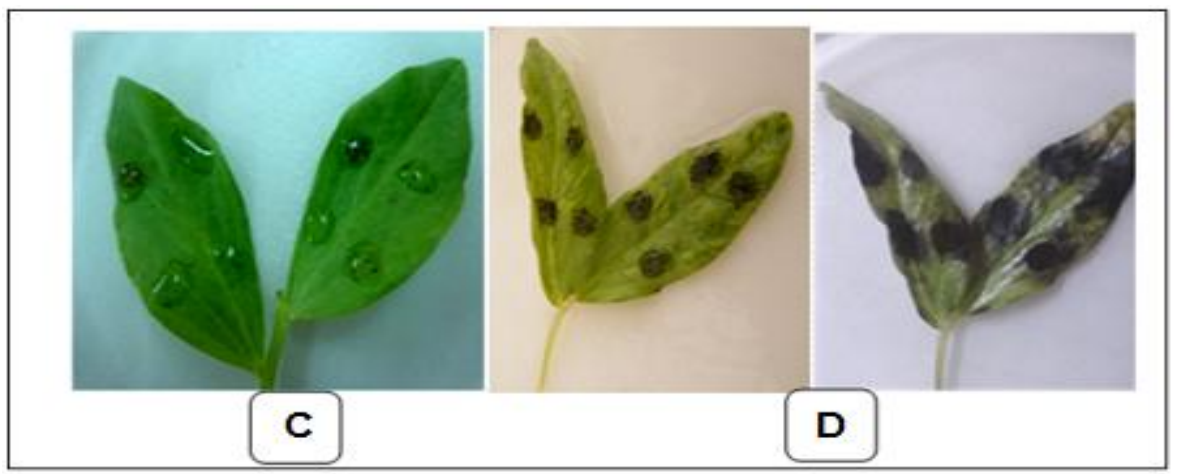

Fig. 2. BYMV stimulates spreading of $B$. fabae (C: BYMV-free leaves \& D: BYMV-infected) 2-days after fungal inoculation.

Table 2. Percentages of infected leaf area on BYMV free and BYMV infected plants following inoculation with $B$. fabae

\begin{tabular}{|c|c|c|c|c|c|}
\hline \multirow{2}{*}{$\begin{array}{c}\text { Leaf } \\
\text { position }\end{array}$} & \multirow{2}{*}{$\begin{array}{c}\text { BYMV } \\
\text { symptom } \\
\text { index }\end{array}$} & \multicolumn{4}{|c|}{ Days after inoculation } \\
\cline { 3 - 6 } & 2 & BYMV-free & BYMV-infected & BYMV-free & BYMV-infected \\
\hline${ }^{*} 1$ & 22.7 & 27.2 & 56.2 & 70.5 \\
\hline 2 & 2 & 20.0 & 24.0 & 52.7 & 66.0 \\
\hline 3 & 2 & 17.7 & 21.7 & 42.0 & 51.7 \\
\hline 4 & 3 & 16.7 & 22.5 & 39.5 & 51.2 \\
\hline 5 & 3 & 12.0 & 15.2 & 43.7 & 50.0 \\
\hline 6 & 4 & 10.7 & 17.7 & 39.5 & 51.0 \\
\hline 7 & 5 & 10.2 & 20.2 & 34.0 & 52.0 \\
\hline \multicolumn{2}{|c|}{ LSD at 0.05} & 1.8 & 3.3 & 3.4 & 1.7 \\
\hline
\end{tabular}

*1: the oldest leaf; 7 : the youngest leaf 
Effect of pre-inoculation with B. fabae on BYMV infectivity

Number of the local lesions of each treatment was counted and presented in Table (3). In comparison with the control (fungus-free plants), BYMV concentrations in fungus- infected leaves were reduced $(13.5,8.2$ in leaf number 2, while it was 16.2, 15.5 in leaf number 6 ). However, the reduction was marked in leaf number 2 rather than in leaf number 6 (8.2 and 15.5).

Table 3. BYMV concentration in plants pre- inoculation with $B$. fabae

\begin{tabular}{|l|c|c|}
\hline \multirow{2}{*}{ Treatment } & \multicolumn{2}{|c|}{ L.L. on Chenopodium amaranticolor } \\
\cline { 2 - 3 } & Leaf $2^{*}$ & Leaf $6^{* *}$ \\
\hline Leaves infected with B. fabae & $* 8.2$ & 15.5 \\
\hline Control & 13.5 & 16.2 \\
\hline LSD at 0.05 & 0.9 & 0.8 \\
\hline \multicolumn{2}{|c|}{ Mean number of local lesions on 4 leaves of C. amaranticolor. . ${ }^{*}=$ oldest leaves; ${ }^{* *}=$ youngest leaves. }
\end{tabular}

Effect of foliar and seed treatment with rhizobacteria (PGPR) on both BYMV and B. fabae

The results of foliar treatment (Table 4) showed that elicitor bioinducers were significantly reduced BYMV and chocolate spot disease incidence and severity percentages. Microbien gave the highest reduction in disease incidence and severity percentages of BYMV $(10 \& 20 \%)$ and in case of $B$. fabae the percentages were (8 \&10.5\%) followed by Rhizobacterin, Cerealin, Nitrobien and finally Biogen, respectively. The same trend was applied on efficacy \% for severity of BYMV \& $B$. fabae as follows Microbien, Rhizobacterin, Cerealin, Nitrobien and Biogen, respectively. Microbien achevied efficacy of $86.7 \%$ in controlling chocolate spot and $75.6 \%$ in controlling BYMV, followed by Rhizobacterin $(84.2,70.0)$ and Cerealin $(80.4,65.9)$. BYMV and $B$. fabae - infected plants grown from rhizobacteria treated seeds showed a significant reduction in disease incidence and severity percentages, compared to plants emerged from non-rhizobacteria treated. Similar trend of the results were found in rhizobacteria treated faba bean seeds (Table 5) against BYMV and B. fabae as in rhizobacteria foliar treatment.

Table 4. Effect of foliar treatment with rhizobacteria (PGPR) on infection with each of BYMV and $B$. fabae

\begin{tabular}{|l|c|c|c|c|c|c|}
\hline \multirow{2}{*}{ Treatment } & \multicolumn{2}{|c|}{ Disease incidence (\%) } & \multicolumn{2}{c|}{ Disease severity (\%) } & \multicolumn{2}{c|}{ Efficacy (\%) for severity of } \\
\cline { 2 - 7 } & BYMV & B. fabae & BYMV & B. fabae & BYMV & B. fabae \\
\hline Biogen & 35.0 & 51.2 & 42.0 & 28.2 & 48.8 & 64.3 \\
\hline Cerealin & 20.0 & 17.0 & 28.0 & 15.5 & 65.9 & 80.4 \\
\hline Microbien & 10.0 & 8.00 & 20.0 & 10.5 & 75.6 & 86.7 \\
\hline Nitrobien & 25.0 & 22.7 & 32.0 & 25.5 & 60.9 & 67.6 \\
\hline Rhizobacterin & 15.0 & 10.8 & 24.0 & 12.5 & 70.7 & 84.2 \\
\hline Control & 90.0 & 91.6 & 82.0 & 79.0 & ----- & ----- \\
\hline LSD at 0.05 & 11.8 & 1.7 & 8.2 & 1.6 & - & - \\
\hline
\end{tabular}


Table 5. Effect of seed treatment with rhizobacteria (PGPR) on infection with each of BYMV and $B$. fabae

\begin{tabular}{|l|c|c|c|c|c|c|}
\hline \multirow{2}{*}{ Treatment } & \multicolumn{2}{|c|}{$\begin{array}{c}\text { Disease incidence } \\
(\%)\end{array}$} & \multicolumn{2}{c|}{$\begin{array}{c}\text { Disease severity } \\
(\%)\end{array}$} & \multicolumn{2}{c|}{$\begin{array}{c}\text { Efficacy (\%) } \\
\text { for severity of: }\end{array}$} \\
\cline { 2 - 7 } & BYMV & B.fabae & BYMV & B. fabae & BYMV & B. fabae \\
\hline Biogen & 45.0 & 52.4 & 42.0 & 33.0 & 53.3 & 58.8 \\
\hline Cerealin & 35.0 & 18.5 & 34.5 & 18.5 & 61.7 & 76.9 \\
\hline Microbien & 20.0 & 12.0 & 27.0 & 27.0 & 70.0 & 66.3 \\
\hline Nitrobien & 40.0 & 23.6 & 37.0 & 29.2 & 58.9 & 63.5 \\
\hline Rhizobacterin & 30.0 & 20.5 & 31.0 & 15.0 & 65.6 & 81.3 \\
\hline Control & 90.0 & 90.2 & 90.0 & 80.0 & ----- & ----- \\
\hline LSD at 0.05 & 10.8 & 2.2 & 1.2 & 4.8 & - & - \\
\hline
\end{tabular}

Determination of some phytochemical component:

Data in (Table 6) indicate that Abscisic acid, Salicylic acid and Jasmonic acid increased significantly in treated plants and in control plants which inoculated with BYMV (challenged control) or B. fabae (challenged control) when compared to absolute control. The highest increase was observed in plants spraying with Microbien and inoculated with BYMV (0.45, 1.43 and 0.91$)$ followed by Rhizobacterin $(0.29,0.92$ and 0.47$)$ and Cerealin $(0.16,0.66$ and 0.45 , respectively). Faba bean plants sprayed with Microbien and inoculated with both BYMV and $B$. fabae also showed high increase in Abscisic acid, salicylic acid and jasmonic acid (0.43, 1.42 and 0.90), followed by Rhizobacterin $(0.27,0.90$ and 0.45$)$. Data in (Table 7) show that BYMV (challenged control) and B. fabae (challenged control), caused significant increase in total phenols in the infected plants (1.87 and 1.82) compared to absolute control (0.82). Plants sprayed with Microbien and inoculated with BYMV or BYMV and B. fabae showed significant increase in total phenols (2.14\& 2.13) followed by Rhizobacterin (1.97\& 1.96) and Cerealin (1.86 \& 1.84), respectively. Increasing the activities of peroxidase and polyphenoloxidase were significantly stimulated with all treatments tested, compared to control plants. The highest activity of peroxidase and polyphenoloxidase have been realized with Microbien in plants inoculated with BYMV or BYMV and B. fabae $(0.68,0.67)$ \& $(0.35,0.33)$ and Rhizobacterin $(0.41,0.40) \&(0.29,0.28)$, respectively. 
Table 6. Effect of foliar treatment with rhizobacteria (PGPR) on abscisic, salicylic and jasmonic acid in 25 and 45 -days old faba bean plants infected with either BYMV and $B$. fabae

\begin{tabular}{|l|c|c|c|c|c|c|}
\hline \multirow{3}{*}{ Treatment } & \multicolumn{2}{|c|}{$\begin{array}{c}\text { Abscisic acid } \\
\text { (ABA) } \\
\text { (mg/100g F.Wt) }\end{array}$} & \multicolumn{2}{c|}{$\begin{array}{c}\text { Salicylic acid } \\
\text { (SA) } \\
\text { (mg/100g F.Wt) }\end{array}$} & \multicolumn{2}{c|}{$\begin{array}{c}\text { Jasmonic acid } \\
\text { (JA) } \\
\text { (mg/100g F.Wt) }\end{array}$} \\
\cline { 2 - 7 } BYMV & $\begin{array}{c}\text { *BYMV+ } \\
\text { B.fabae }\end{array}$ & BYMV & $\begin{array}{c}\text { *BYMV+ } \\
\text { B.fabae }\end{array}$ & BYMV & $\begin{array}{c}\text { *BYMV+ } \\
\text { B.fabae }\end{array}$ \\
\hline Biogen & 0.0 & 0.0 & 0.3 & 0.2 & 0.2 & 0.2 \\
\hline Cerealin & 0.2 & 0.1 & 0.7 & 0.6 & 0.4 & 0.4 \\
\hline Microbien & 0.4 & 0.4 & 1.4 & 1.4 & 0.9 & 0.9 \\
\hline Nitrobien & 0.1 & 0.1 & 0.4 & 0.4 & 0.4 & 0.4 \\
\hline Rhizobacterin & 0.3 & 0.3 & 0.9 & 0.9 & 0.5 & 0.4 \\
\hline Control & 0.1 & 0.1 & 0.3 & 0.1 & 0.2 & 0.1 \\
\hline $\begin{array}{l}\text { Absolute } \\
\text { control }\end{array}$ & 0.0 & 0.0 & 0.0 & 0.0 & 0.1 & 0.1 \\
\hline LSD at 0.05 & 0.0 & 0.0 & 0.0 & 0.0 & 0.1 & 0.1 \\
\hline
\end{tabular}

*plants inoculated with both BYMV and $B$. fabae

Table 7. Effect of foliar treatment with rhizobacteria (PGPR) on total phenols, peroxidase and polyphenoloxidase activities in 25 and 45 -days old faba bean plants infected with either BYMV and $B$. fabae

\begin{tabular}{|l|c|c|c|c|c|c|}
\hline \multirow{2}{*}{ Treatment } & \multicolumn{2}{|c|}{$\begin{array}{c}\text { Phenols } \\
(\mathrm{mg} / 100 \mathrm{~g} \text { F.Wt })\end{array}$} & \multicolumn{2}{c|}{$\begin{array}{c}\text { Peroxidase } \\
(\mu \mathrm{g} / \mathrm{g} \text { F.Wt })\end{array}$} & \multicolumn{2}{c|}{$\begin{array}{c}\text { Polyphenoloxidase } \\
(\mu \mathrm{g} / \mathrm{g} \text { F.Wt })\end{array}$} \\
\cline { 2 - 7 } & $\begin{array}{c}\text { BYM } \\
\mathrm{V}\end{array}$ & $\begin{array}{c}\text { *BYMV+ } \\
\text { B.fabae }\end{array}$ & BYMV & $\begin{array}{c}\text { BYMV+ } \\
\text { B.fabae }\end{array}$ & BYMV & $\begin{array}{c}\text { BYMV+ } \\
\text { B.fabae }\end{array}$ \\
\hline Biogen & 1.3 & 1.3 & 0.3 & 0.2 & 0.2 & 0.2 \\
\hline Cerealin & 1.9 & 1.8 & 0.4 & 0.4 & 0.3 & 0.3 \\
\hline Microbien & 2.1 & 2.1 & 0.7 & 0.7 & 0.3 & 0.3 \\
\hline Nitrobien & 1.5 & 1.4 & 0.4 & 0.3 & 0.3 & 0.2 \\
\hline Rhizobacterin & 2.0 & 2.0 & 0.4 & 0.4 & 0.3 & 0.3 \\
\hline Control & 1.9 & 1.8 & 0.3 & 0.3 & 0.3 & 0.2 \\
\hline $\begin{array}{l}\text { Absolute } \\
\text { control }\end{array}$ & 0.8 & 0.8 & 0.1 & 0.1 & 0.2 & 0.2 \\
\hline LSD at 0.05 & 0.18 & 0.16 & 0.02 & 0.01 & 0.03 & 0.02 \\
\hline
\end{tabular}

*plants inoculated with both BYMV and B. fabae

\section{Discussion}

The present work has shown that infection of faba bean plants by BYMV influenced the host response to infection by B. fabae. Similar result was found in barely infected by Barely yellow dwarf virus and Cladosporium sp. (Ajyi and Dewar, 1983). So B. fabae disease development was enhanced by prior virus infection. This result is in the harmony with Omar et al. (1986), who found that the 
infection of faba bean with BYMV modified the response of the plant to subsequent infection by Botrytis. The age of leaves have a great influence of infection with $B$. fabae. As a rule, the oldest leaves were more affected than the youngest ones. Moreover, lesion grades were much higher and spread more rapidly on the oldest leaves followed by the youngest leaves with clear virus symptoms than did the corresponding virus free ones.

The extent of necrosis beneath inoculum droplets was greater on virus- infected than virus free leaves within one day of $B$. fabae inoculation, which probably reflects a combination of changes in the number of successful infections and the number of necrotic cells per infection beneath each droplet. Differences in infection grade increased further after 3 days, followed by more rapid and extensive lesion spread into uninoculated tissue and denser sporulation on virus- infected leaves. On detached leaves tests, B. fabae lesion development and sporulation on virus free leaves increased progressively with leaf age. In this concern Mansfield \& Deverall (1974) found that lesion development is more extensive and rapid on old leaves. The mechanism of the increase in susceptibility of virus- infected faba bean plants to $B$. fabae may be explained on the fact that: (1) virus infection increased permeability of cell membranes of the leaves and (2) the high levels of carbohydrates and amino acids leaked increased spore germination of Botrytis and possibly increased the development of the infection. Such nutrient, present in the host exudates, provide possibly a chemotrophic stimulus for the initiation and growth of the germ tube or the infection hypae. Also, leaves of virus- infected faba bean plants showing signs of senescence, as a result of reduction in chlorophyll content, those leaves seem likely to be more susceptible to Botrytis infection. On the other hand, the number of local lesions of pre-inoculation with $B$. fabae decreased the local lesion number produced by BYMV on Ch. amaranticolor. B. fabae- infected plant tissues may decrease the infectivity of BYMV. This result is in harmony with Omar (1984), who found that BYMV concentrations in infected plants were comparatively reduced.

Plant growth -promoting rhizobacteria (PGPR) are among the various groups of plant associated microorganisms that can elicit a natural plant defense (Kamal et al., 2014). The obtained results showed that both foliar and seed treatment with rhizobacteria significantly reduced BYMV and B. fabae disease severity. Similar results were reported by Rabie (1998) and Elbadry et al. (2006). Foliar spraying of $B$. cereus and P. fluorescens reduced severity of Botrytis gray mold in chickpea (Kishore and Pande, 2007). Reduction in disease incidence of symptoms of BYMV was reported following seed treatment of faba bean by strain of R. leguminosarum (Al-Ani and Adhab, 2012). BYMV-inoculated plants grown from rhizobacterium-treated seeds showed a highly reduction in disease incidence percentages (Al-Ani and Adhab, 2013). Bio- primed faba bean seeds with $P$. fluorescencs reduced the disease incidence and severity as well as infection processes of B. fabae (Alemu and Alemu, 2013).

Foliar treatment with Microbien, Rhizobacterin and Cerealin on the challenged plants with BYMV alone and with both BYMV and B. fabae, caused a significant increase in abscisic acid (ABA) and salicylic acid (SA) as well as jasmonic acid (JA) level in plant leaves, it is reasonable to assume that several plant hormones either 
individually or in combinations modulate the complex processes involved in plant defense signalling pathways. The first hormones to be marked as central players in defense against plant pathogens were salicylic acid, jasmonic acid and ethylene (Glazebrook, 2005), with roles more recently attributed to abscisic acid, gibberellins, and auxin (Navarro et al., 2008). Methyl jasmonate are known to increase the formation of phenolic compounds by stimulating the phenylpropanoid pathway and plays an important role in the induction of defense mechanism against Beet mosaic virus infection (Haggag et al., 2010). Faba bean seed bacterization with $R$. leguminosarum induced resistance against $B$. fabae and increased the level of salicylic acid (Abdelazez et al., 2014). Salicylic acid can trigger the systemic acquired resistance pathways as well as ISR in some plant species. SA induction is often linked with pathogensis- related protein accumulation, mainly PR-1. Jasmonic acid was found as the major defense-signaling molecule associated with the wound response (Dong, 1998). ABA also was found to play a major role in signalling due to biotic and abiotic stress, but disease resistance may differ with the type of pathogen and timing of applications, ABA promotes resistance in some plantpathogen interactions, whereas it increases susceptibility in others (Forcat et al., 2008).

Phenols and defense enzymes such as peroxidase and polyphenoloxidase activities were increased in faba bean plants infected with both BYMV and B. fabae and treated with Microbien, Cerealin or Rhizobacterin. In this respect, Rabie (1998) reported that total and free phenolic compounds increased in B. fabae infected broad bean when the plant was pre-inoculated with R. leguminosarum. For peroxidase and polyphenoloxidase, data describing increasing of its activity with all treatments in relative to controls. It is quite evident that, the greatest activities were achieved by Microbien on the infected plants more than on the healthy plants, indicating induction of systemic resistant (ISR). Also, it indicates that the PGPR treatment was effective to induce peroxidase and polyphenoloxidase activities. These results are in accordance with Elbadry et al. (2006), who stated that induction of peroxidase activity was significantly increase in faba bean plants treated with $R$. leguminosarum and infected with BYMV compared to the untreated control. On the contrary, lowest peroxidase activities were achieved in the infected untreated plants, indicating suppression of the defense mechanism strongly due to viral or fungal infection.

PGPR improves the physical and mechanical strength of the cell wall as well as changing the physiological and biochemical reaction of the host leading to the synthesis of defense chemicals against the challenge pathogen (Ramamoorthy et al., 2001). It is well known that PGPR induce structural modification of the cell wall in response to pathogenic attack. Seed treatment of PGPR in bean induces the lignification of cell wall (M'Piga et al., 1997). This type of rapid defence reaction does not allow the pathogen to invade and also offers the host plant sufficient time to employ other defence mechanisms. Normally ISR by PGPR is associated with the accumulation of PR proteins; (pathogensis-related proteins), synthesis of phytoalexin and other secondary metabolites (Viswanathan and Samiyappan, 1999). Several substances produced by rhizobacteria have been related to pathogen control, such as siderophores, antibiotics and lytic enzymes as chitinase and protease (Beneduzi et al., 2012 \& Compant et al., 2005).

Egypt. J. Phytopathol., Vol. 44, No. 1 (2016) 
In conclusion, under our experimental conditions, rhizobacteria seems to be promising inducers for ISR in faba bean (Vicia faba L.) to a challenge BYMV or $B$. fabae infection under greenhouse conditions. This result is very important since it may offer a simple, environmentally safe and economically accepted mean to protect faba bean plants from BYMV or B. fabae infection. However, additional studies are needed to confirm these results under field conditions.

\section{Ref e r e n c e s}

Abdelazez, H.M.; Nassr, R. E.A.A. and El-Dougdoug, K.A. 2014. Impact of faba bean seed bacterization with Rhizobium legumonisarum for enhanced plant growth and biocontrol diseases. J. Microbiol., 4(6): 187-192.

Ajyi, O. and Dewar, A.M. 1983. The effect of barely yellow dwarf virus, aphids and honeydew on Cladosporium infection of winter wheat and barley. Ann. Appl. Biol., 102: 57-65.

Al-Ani, R.A. and Adhab, M.A. 2012. Protection of melon plants against Cucumber mosaic virus infection using Pseudomonas fluorescens biofertilizer. Afr. J. Biotechnol., 11(100): 16579-16585.

Al-Ani, R.A. and Adhab, M.A. 2013. Bean yellow mosaic virus (BYMV) on broad bean: characterization and resistance induced by Rhizobium leguminosarum. J. Pure Appl. Microbiol., 7(1): 135-142.

Alemu, F. and Alemu, T. 2013. Antifungal activity of secondary metabolities of Pseudomonas fluorescens isolates as a biocontrol agent of chocolate spot disease (B. fabae) of faba bean in Ethiopia. Afr. J. Microbiol. Res., 7(47): 5364-5373.

Ataga, A.E.; Eptont, H.A.S. and Frost, R. R. 1999. Interaction of virus- infected celery and Septoria apiicola. Plant Pathol., 48: 620-626.

Beneduzi, B.; Ambrosini, A. and Passaglia, L.M.P. 2012. Plant growth- promoting rhizobacteria (PGPR): Their potential as antagonists and biocontrol agents. Genet. Mol. Biol., 35(4): 1044-1051.

Bernier, C.C.; Hanounik, S.B.; Hussein, M.M. and Mohamed, H.A. 1984. Rating scale for faba bean diseases in Nile vally. ICARDA Inform. Bull., 3. 37 pp.

Comeau, A. and Pelletier, J. 1976. Predisposition to Septoria leaf blotch in oats affected by Barley yellow dwarf virus. Can. J. Plant Sci., 56: 13-19.

Compant, S.; Duffy, B.; Nowak, J.; Clement, C. and Baraka, E.A. 2005. Use of plant growth promoting bacteria for biocontrol of plant diseases: principles, mechanisms of action, and future prospects. Appl. Environ. Microbiol., 71(9): 4951-4959.

Converse, R.H. and Martin, R.R. 1990. ELISA methods for plant viruses. Pages: 179-196. In: "Serological Methods for Detection and Identification of Viral and Bacterial Plant Pathogens. R. Hampton, E. Ball, S. De Boer (eds.). APS Press, St. Paul, Minn, USA, 389 p. 
Dileep Kumar, B.S. and Dube, H.C. 1992. Seed bacterization with a fuorescent Pseudomonads for enhanced plant growth, yield and disease control. Soil Biol. Biochem., 24: 539-542.

Dong, X. 1998. SA, JA, ethylene, and disease resistance in plants. Current Opinion Plant Biol., 1: 316-329.

Duncan, D.B. 1995. Multiple Ranges and Multiple F Test. Biometrics, 11: 1-42.

Elbadry, M.; Taha, R.M.; El-Dougdoug, K.A. and GamalEldin, H. 2006. Induction of systemic resistance in faba bean (Vicia faba L.) to Bean yellow mosaic potyvirus (BYMV) via seed bacterization with plant growth promoting rhizobacteria. J. Plant Dis. Prot., 113(6): 247-25.

El-Bramawy, M.A.S. and Shaban, W.I. 2010. Effects of potassium fertilization on agronomic characters and resistance to chocolate spot and rust diseases in faba bean. Tunis. J. Plant Prot., 5(2): 131-150.

El-Tahlawy, M.; Rizkallah, L.R. and Abdelkader, H.S. 2005. Field evaluation of different faba bean genotypes for seed transmission ability of some viruses using serological techniques. Egypt. J. Virol., 2: 225-237.

Evans, T.A. and Stephens, C.T. 1989. Increased susceptibility to Fusarium crown and root rot in virus-infected Asparagus. Amer. Phytopathol. Soc., 79(3): 253-258.

Forcat, S.; Bennett, M.H.; Mansfield, J.W. and Grant, M.R. 2008. A rapid and robust method for simultaneously measuring changes in the phytohormones $\mathrm{ABA}, \mathrm{JA}$ and SA in plants following biotic and abiotic stress. Plant Methods, 4(16): $1-8$.

Galeazzi, M.A.; Sgarbieri, V.C.; Garbieri, S. and Constantinides, M. 1981. Isolation, purification and physiochemical of polyphenol oxidase (PPO) from a dwarf variety of banana. J. Food Sci., 46: 150-155.

Glazebrook, J. 2005. Contrasting mechanisms of defense against biotroohic and necrotrophic pathogens. Annu. Rev. Phytopathol., 43: 205-227.

Haggag, W.M.; Mahmoud, Y.S. and Farag, E.M. 2010. Signaling necessities and function of polyaminase/jasmonate dependent induced resistance in sugar beet against Beet mosaic virus (BtMV) infection. New York Sci. J., 3(8): 95-103.

Jenns, A.E. and Kuc, J. 1977. Localized infection with Tobacco necrosis virus protects cucumber against Colletotrichum lagenarium. Physiol. Plant Pathol., 11: 207-212.

Kamal, R.; Gusain, Y.S. and Kumar, V. 2014. Interaction and symbiosis of AM fungi, Actinomycetes and plant growth promoting rhizobacteria with plants: strategies for improvement of plants healthy and defense system. Inter. J. Curr. Microbiol. Appl. Sci., 3(7): 564-585.

Kishore, G.K. and Pande, S. 2007. Chitin- supplemented foliar application of chitinolytic Bacillus cereus reduces severity of Botrytis gray mold disease in chickpea under controlled conditions. Letters Appl. Microbiol., 44: 98-105. 
Koeing, R.C. 1981. Indirect ELISA methods for broad specifity detection of plant viruses. J. Gen. Virol., 55: 53-62.

Leach, R. and Moore, K.G. 1966. Sporulation of Botrytis fabae on agar culture. T. Brit. Mycol. Soc., 49: 593-601.

Lee, B.; Martin, P. and Bangerth, F. 1989. The effect of sucrose on the levels of abscisic acid, indoleacetic acid and zeatin/zeatinriboside in wheat ears growing in liquid culture. Physiol. Plant., 77: 73-80.

Mahgoub, H.A.; Wipf-Scheibel, C.; Delecolle, B.; Pitrat, M.; Dafalla, G. and Lecoq, H. 1997. Melon rugose mosaic virus: characterization of an isolate from Sudan and seed transmission in melon. Plant Dis., 81: 656-60.

Mahmoud, Y.A.G.; Abu El Souod, S.M.; Alsokari, S.; Ismaeil, A.; Attia, M.; and Ebrahim, M.K. 2011. Recent approaches for controlling brown spot disease of Faba Bean in Egypt. Egypt. Acad. J. Biol. Sci., 3(1): 41-53.

Maliak, C.P. and Singh, M.B. 1980. Estimation of Total Phenols in Plant Enzymology and histoenzymology.Kalyani Publishers, New Delhi, 286 p.

Mansfield, J.W. and Deverall, B.J. 1974. The rates of fungal development and lesion formation in leaves of Vicia faba during infection by Botrytis cinerea and Botrytis fabae. Ann. Appl. Biol., 76: 77-89.

Maxwell, D.P. and Bateman, D.F. 1967. Changes in the activities of some oxidases in extracts of Rhizoctonia infected bean hypocotyl in relation to lesion maturation. Phytopathology, 57: 132-136.

M'Piga, P.; Belanger, R.R.; Paulitz, T.C. and Benhamou, N. 1997. Increased resistance to Fusarium oxysporum f.sp. radicis lycopersici in tomato plants treated with the endophytic bacterium Pseudomonas fluorescens strain 63-82. Physiol. Mol. Plant Pathol., 50: 301-320.

Navarro, L.; Bari, R.; Achard, P.; Lison, P.; Nemri A.; Harberd, N.P. and Jones, J.D. 2008. DELLAS control plant immune responses by modulating the balance of jasmonic acid and salicylic acid signalling. Curr. Biol., 18(9): 650-655.

Noordam, D. 1973. Identification of Plant Viruses. Methods and Experiments. Centre for Agricultural Publishing and Documentation (Pudoc) Wageningen. $207 \mathrm{p}$.

Omar, S.A.M. 1984. Disease interaction and host response in Vicia faba. Ph.D. Thesis, University of London (Wye College), 300p.

Omar, S.A.M.; Bailiss, K.W. and Chapman, G.P. 1986. Virus- induced changes in the response of faba bean to infection by Botrytis. Plant Pathol., 35: 86-92.

Park, S. W.; Kaimoyo, E.; Kumar, D.; Mosher, S and Kicssig, D. F. 2007. Methyl salicylate is a critical mobile signal for plant systemic acquired resistance. Sci. Washington, 318: 113-116. 
Pieczarka, D.J. and Zitter, T.A. 1981. Effect of interaction between two viruses and Rhizoctonia on pepper. Plant Dis., 65(5): 404-406.

Rabie, G.H. 1998. Induction of fungal disease resistance in Vicia faba by inoculation with Rhizobium leguminosarum and vesicular- arbuscular mycorrhizal fungi. Mycopathol.,141: 159-166.

Radwan, D.E.; Lu, G.; Fayez, K.A. and Mahmoud, S.Y. 2008. Protective action of salicylic acid against Bean yellow mosaic virus infection in Vicia faba leaves. J. Plant Physiol., 165(8): 845-857.

Ramamoorthy, V.; Viswanathasn, R.; Raguchander, T.; Prakasam, V. and Samiyappan, R. 2001. Induction of systemic resistance by plant growth promoting rhizobacteria in crop plants against pests and diseases. Crop Prot., 20: $1-11$.

Reddy, D.V.R.; Amin, P.W.; McDonald, D. and Ghanekar, A.M. 1983. Epidemiology and control of groundnut bud necrosis and other diseases of legume crops in India caused by Tomato spotted wilt virus. Pages: 93-102. In: Plant Viruses Epidemiology: The Spread and Control of Insect-Borne Viruses. Plumb, J.M., Thresh, J.M.(eds.). CPS Press., USA.

Rewal, H.S. and Jhooty, J.S. 1985. Differential response of wheat varieties to systemic fungicides applied to Ustilago tritici (Pers.). Rostr. Indian J. Agric. Sci., 55: 548-549.

Saber, W.I.A.; Abd El-HaiK, M. and Ghoneem, K.M. 2009. Synergistic effect of Trichoderma and Rhizobium on both biocontrol of chocolate spot disease and induction of nodulation, physiological activities and productivity of Vicia faba. Res. J. Microbiol., 4: 286-300.

Van Loon, L.C.; Bakker, P.A.H.M. and Pieterse, C.M.J. 1998. Systemic induced resistance by rhizosphere bacteria. Annu. Rev. Phytopathol., 36: 453-483.

Verhagen, B.W.; Trotel, A.P.; Couderchet, M.; Hofte, M. and Aziz, A. 2010. Pseudomonas spp.-induced systemic resistance to Botrytis cinerea is associated with induction and priming of defense responses in grapevine. $J$.Exp. Bot., 61(1): 249-260.

Viswanathan, R. and Samiyappan, R. 1999. Induction of systemic resistance by plant growth promoting rhizobacteria against red rot disease caused by Colletotrichum falcatum in sugarcane. Proc. Sugar Technol. Assoc. India, 61: 24-39.

Wydra, K. and Verdier, V. 2002. Occurrence of cassava diseases in relation to environmental, agronomic and plant characteristics. Agric. Ecosystem \& Environ., 93: 211-226.

(Received 15/03/2016; in revised form 24/04/2016) 


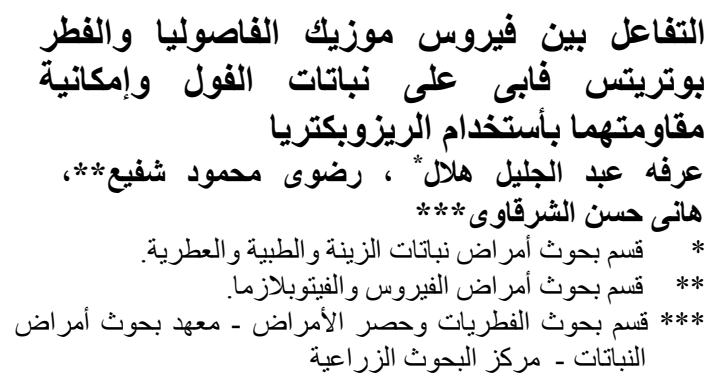

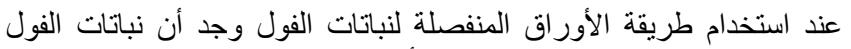

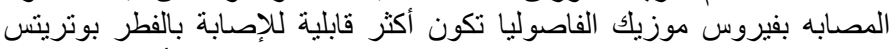

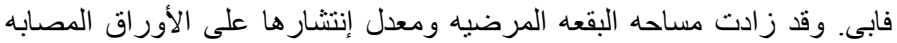

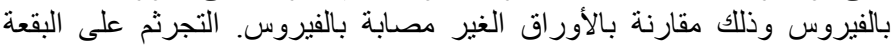

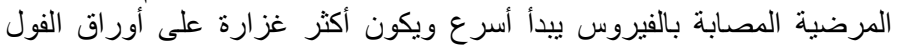

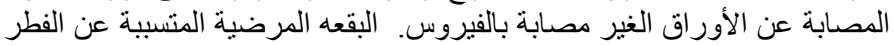

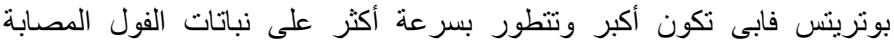

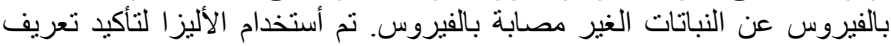

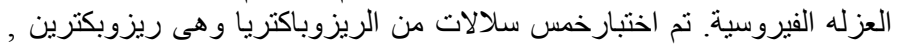

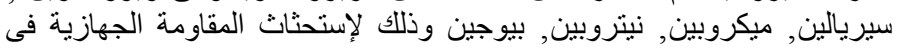

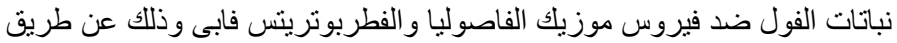

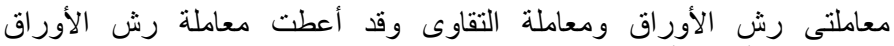

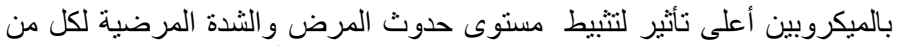

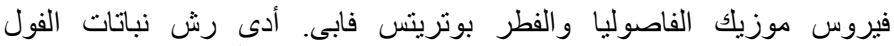

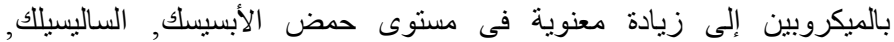

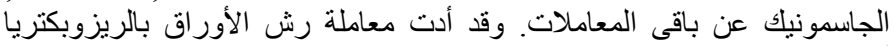

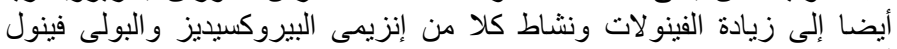
أكسيديز. 